\title{
PERGESERAN KATA SAPAAN DALAM BAHASA SIMALUNGUN DI KECAMATAN LABUHAN DELI
}

\author{
Gunawan Purba \\ Program Studi Linguistik (S2), Program Pascasarjana \\ Fakultas Ilmu Budaya Universitas Sumatera Utara \\ gunpur.wan@gmail.com
}

\begin{abstract}
ABSTRAK
Penelitian ini berjudul Pergeseran Kata Sapaan Dalam Bahasa Simalungun di Kecamatan Labuhan Deli, yang bertujuan untuk : 1. Mendeskripsikan kata sapaan yang digunakan pada masyarakat Simalungun di Kecamatan Labuhan Deli, 2. Menemukan bentuk kata sapaan apa saja yang sudah bergeser pada masyarakat Simalungun di Kecamatan Labuhan Deli, 3. Menemukan faktor-faktor yang mempengaruhi pergeseran kata sapaan pada masyarakat Simalungun di Kecamatan Labuhan Deli. Teori yang digunakan dalam penelitian ini adalah teori Kata Sapaan menurut Fasold dengan konsep kata sapaan Simalungun menurut Sinaga, teori Ranah Penggunaan Bahasa menurut Fishman, dan faktor-faktor pergeseran bahasa menurut Fasold. Metode yang digunakan dalam penelitian ini adalah metode kualitatif dengan mengadopsi teori Miles dan Huberman. Hasil yang diperoleh setelah data dianalisis adalah kata sapaan yang mengalami pergeseran dalam bahasa Simalungun yang tertinggi adalah pada kelompok usia remaja, faktor-faktor yang menyebabkan kata sapaan tersebut mengalami pergeseran adalah bilingualisme masyarakat, migrasi dan urbanisasi, peralihan antar generasi, industrialisasi dan bahasa asing yang lebih berprestise.

Kata Kunci : Pergeseran, Kata Sapaan, Bilingualisme/kedwibahasaan.
\end{abstract}

\begin{abstract}
This study, entitled "Pergeseran Kata Sapaan Dalam Bahasa Simalungun di Kecamatan Labuhan Deli" which aims to 1.Describe the greeting word which used in Simalungun society in Labuhan Deli disctrict,2.Find the form of greeting word which has shifted in Simalungun society in Labuhan deli district,3.Find the elements that influence the shifting of greeting word in Simalungun society in Labuhan Deli district. The Theory which is used for this study is according to Fasold theory in concept Simalungun greeting according to Sinaga, Ranah theory, The usage of Language according to Fishman, and the elements of Language shifting according to Fasold. This study uses the qualitative research by adopting theories of Miles and Huberman. The result of the data was the
\end{abstract}


Greeting word of shifting in Simalungun language was highest in the group of teenagers, the factors that cause the shifting of Greeting word is bilingualism society, migration and urbanization, transition between generations, industrialization and foreign languages are more prestigious.

\section{PENDAHULUAN}

Pergeseran bahasa (language shift) merupakan salah satu bidang kajian dari sosiolinguistik. Pergeseran bahasa merupakan perubahan secara tetap dalam pilihan bahasa untuk keperluan sehari-hari. Pergeseran bahasa terjadi karena adanya perpindahan penduduk yang mengakibatkan adanya percampuran penduduk dalam suatu daerah, yang mengakibatkan timbulnya bahasa lain yang digunakan di daerah itu sendiri sehingga berdampak pada masyarakat untuk harus memilih bahasa mana yang cocok digunakan dengan budaya yang terdapat pada daerah tersebut.

Fenomena pergeseran bahasa dapat juga terjadi jika suatu komunitas secara kolektif meninggalkan bahasanya dan memilih bahasa lain. Artinya, pergeseran bahasa yang berlarut-larut akan berdampak terhadap kepunahan sebuah bahasa. Kepunahan bahasa menurut Dressler (1992:196), biasanya dipahami berdasarkan dua praanggapan, yaitu: (1) kedwibahasaan atau kemultibahasaan dan (2) pergeseran bahasa akibat desakan bahasa dominan. Pergeseran bahasa meliputi transisi yang berangsur-angsur (sampai ke ranah penggunaan) dari dwibahasawan yang tidak stabil sampai akhirnya menjadi ekabahasawan, dan akibat transisi ini adalah kepunahan atau kematian bahasa.

Penggalan dialog di bawah ini merupakan suatu fenomena yang terjadi di tengah-tengah masyarakat Simalungun di desa Pematang Johar. Sapaan/panggilan telah mengalami pergeseran pada masyarakat Simalungun di desa ini.

1. A : domma lao mamakmu? 'udah pergi ibumu?'

B : domma kian, pakon bibi Meot nokan ia lao. 'udah kian. Sama bibi Meot tadi dia pergi'

A : oohh nai do? 'oohh gitunya?' 
B : domma nokkan pagi. 'sudah tadi pagi'

Kata sapaan mamak, kian, dan bibi pada contoh di atas merupakan kata sapaan yang tidak sesuai dengan sapaan Simalungun yang lazimnya digunakan oleh penutur bahasa Simalungun karena dalam bahasa Simalungun kata-kata sapaan tersebut seharusnya inang, inanggian/inang anggi dan amboru.

Selain itu, terdapat juga kata sapaan lain yang mulai bergeser misalnya sapaan terhadap ayah kandung. Masyarakat Simalungun menggunakan kata sapaan amang dalam pemanggilan terhadap orang tua laki-laki, namun sekarang jarang sekali ditemukan masyarakat Simalungun menggunakan kata amang untuk melakukan panggilan terhadapat ayah, tetapi telah tergeser dari kata sapaan lain seperti bapak, papa dan lain sebagainya.

Berdasarkan keterangan di atas peneliti melihat lebih jauh lagi bagaimana perubahan kata dari sapaan kekerabatan dalam bahasa Simalungun untuk mengetahui bentuk kata sapaan apa saja yang sudah bergeser serta apa yang menjadi penyebab terjadinya pergeseran kata sapaan tersebut, karena apabila hal ini tidak diteliti maka akan dapat menimbulkan pergeseran yang lebih jauh lagi sehingga nantinya banyak kata sapaan bahasa Simalungun yang akan punah. Oleh karena itu peneliti mengambil judul "Pergeseran Kata Sapaan Dalam Bahasa Simalungun di Kecamatan Labuhan Deli”.

\section{TINJAUAN PUSTAKA}

\section{Pergeseran Bahasa dan Konsep Pergeseran Bahasa}

Menurut Fasold (1984: 213) pergeseran bahasa merupakan hasil dari proses pemilihan bahasa dalam jangka waktu yang sangat panjang. Artinya pergeseran bahasa tidak serta merta dapat terjadi begitu saja dalam waktu singkat melainkan ada proses dalam jangka waktu yang relatif lama. Pergeseran bahasa menunjukan adanya suatu bahasa yang benar-benar ditinggalkan oleh komunitas penuturnya. Hal ini berarti bahwa ketika pergeseran bahasa terjadi, anggota suatu komunitas bahasa secara kolektif lebih memilih menggunakan bahasa baru daripada bahasa lama yang secara tradisional biasanya digunakan. Pada awalnya pergeseran tersebut datang dengan begitunya tetapi pada saat tertentu akan memungkinkan untuk kembali ke bahasa yang awalnya digunakan. Ini merupakan suatu proses generasi atau faktor usia pengguna bahasa. Ada kalanya suatu generasi menggeser suatu bentuk bahasa namun pada saat tertentu juga akan mengembalikan bahasa lamanya kembali. Faktor generasi ini merupakan suatu ancaman bagi terjadinya kepunahan bahasa apabila mereka nantinya lupa terhadap bahasa awal yang mereka gunakan.

\section{Proses Pergeseran Bahasa}

Pergeseran bahasa biasanya terjadi di negara, daerah atau wilayah yang memberi harapan untuk kehidupan sosial ekonomi yang lebih baik, sehingga mengundang imigran/transmigran untuk mendatanginya. 
Fishman (1972) telah menunjukan terjadinya pergeseran bahasa para imigran di Amerika. Secara sederhana pergeseran bahasa para imigran itu dilukiskan dalam bagan di bawah ini.

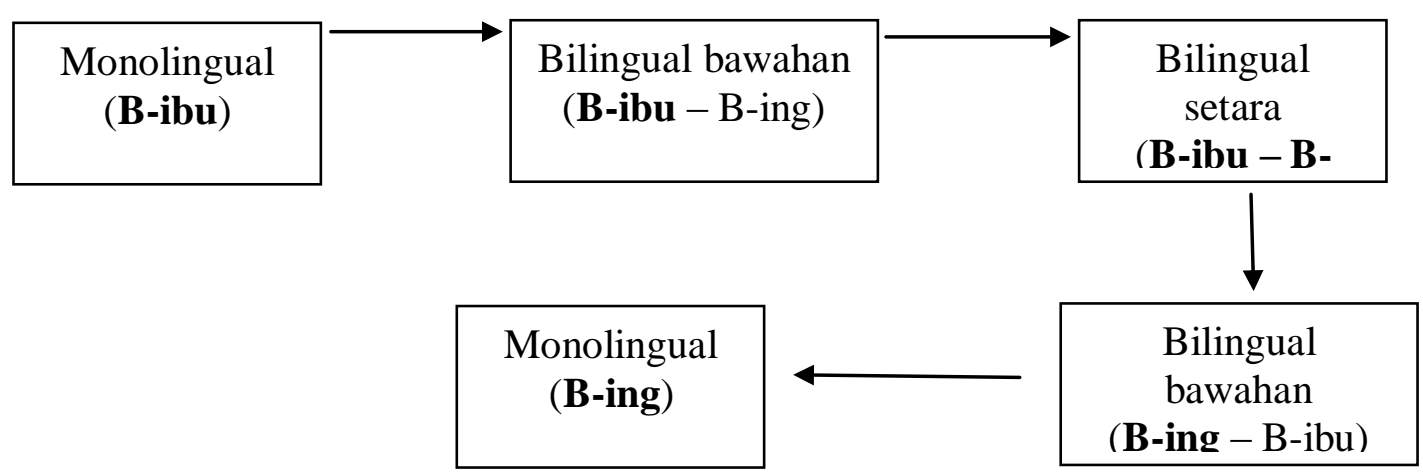

Bagan 01. Proses terjadinya pergeseran bahasa imigran di Amerika.

\section{Ranah Penggunaan Bahasa}

Bahasa sesungguhnya hanya ada dalam pikiran para pemakainya, dan akan berfungsi ketika para pemakainya berhubungan satu sama lain secara alami dalam lingkungan sosial dan alamiah mereka. Interaksinya dengan bahasa lain dalam pikiran dua atau banyak penutur menyebabkan multifungsi bahasa. Bagi penutur yang dwibahasawan, konsekuensi penguasaan lebih dari satu bahasa menimbulkan peristiwa pilihan bahasa. Dalam sebuah komunitas (guyub), tingginya intensitas penggunaan salah satu bahasa akan mempengaruhi vitalitas bahasa yang lain.

\section{Sistem Sapaan Masyarakat Simalungun}

Sistem sapaan dalam suatu wilayah masyarakat memiliki hubungan yang sangat erat antara orang yang menyapa dengan orang yang disapa. Fasold (1993: 31) Address forms arethe speakers use to desigenate the person they are talking to while they are talking to them. In most language, they are two main kinds of address form: name and second person pronouns. Dalam berkomunikasi masyarakat Simalungun selalu memiliki panggilan terhadap lawan bicaranya, baik dengan sapaan nama langsung ataupun sapaan yang memang dibuat berdasarkan hasil dari berkenalan melalui marga atau martarombo.

Bentuk sapaan yang dipakai oleh masyarakat Simalungun berdasarkan buku yang disusun oleh (Salmon Sinaga dkk, 2002: 4-7) berdasarkan hasil seminar Kesepamahaman Adat Simalungun yang dihadiri oleh para praktisi Simalungun tanggal 9-10 Agustus 2002 di Pematang Siantar adalah sebagai berikut: 
Bentuk Kata Sapaan Masyarakat Simalungun di Kecamatan Labuhan Deli

\begin{tabular}{|c|c|c|}
\hline No & $\begin{array}{l}\text { Sapaan Bahasa } \\
\text { Simalungun }\end{array}$ & Makna \\
\hline 1 & Ompung & Orang tua dari ayah atau ibu \\
\hline 2 & Bapa/Amang & Sapaan untuk ayah kandung \\
\hline 3 & Inang & Ibu kandung yang melahirkan \\
\hline 4 & Abang & Anak laki-laki yang duluan lahir dari kita \\
\hline 5 & Botou & Saudara perempuan \\
\hline 6 & Anggi & Adik laki-laki \\
\hline 7 & Amboru & Saudara perempuan dari ayah \\
\hline 8 & Makkela & Suami dari amboru \\
\hline 9 & Tulang & Saudara laki-laki dari ibu \\
\hline 10 & Anturang & Istri dari Tulang \\
\hline 11 & Parumaen & Istri dari anak \\
\hline 12 & Nasibesan & Istrinya adik/abang dari istri kita \\
\hline 13 & Hela & Suami dari putri kita \\
\hline 14 & Gawei/Eda & $\begin{array}{l}\text { (Sapaan timbal balik bagi perempuan) istri dari adik/abang } \\
\text { kita }\end{array}$ \\
\hline 15 & Lawei & $\begin{array}{l}\text { (Sapaan timbal balik bagi laki-laki) suami dari kakak/adik } \\
\text { perempuan kita }\end{array}$ \\
\hline 16 & Botou Bапиа & $\begin{array}{l}\text { Sapaan untuk anak perempuan dari amboru (kalau laki- } \\
\text { laki), sapaan untuk anak laki-laki dari Tulang (kalau } \\
\text { perempuan) }\end{array}$ \\
\hline 17 & Pahompu & Anak dari anak kita (cucu) \\
\hline 18 & Nono & Cucu dari anak kita \\
\hline 19 & Ompung nini & ayah dari Ompung kita \\
\hline 20 & $\begin{array}{l}\text { Bapa tua/Bapa } \\
\text { godang }\end{array}$ & Abang dari ayah \\
\hline 21 & $\begin{array}{l}\text { Inang tua/Inang } \\
\text { godang }\end{array}$ & Istri dari abangya ayah \\
\hline 22 & Bapa tongah & $\begin{array}{l}\text { Saudara laki-laki dari ayah kita, yang kelahirannya tidak } \\
\text { paling tua dan tidak paling muda, melainkan posisinya } \\
\text { berada diantara yang paling tua dan yang paling muda }\end{array}$ \\
\hline 23 & Inang tongah & Istri dari Bapa Tongah \\
\hline 24 & Bapagian/Bapaanggi & Adik paling muda laki-laki dari ayah kita \\
\hline 25 & Inanggian/Inanganggi & Istri dari Bapa gian/Bapa anggi kita \\
\hline 26 & Sanina & Saudara sesama marga \\
\hline 27 & Panogolan & $\begin{array}{l}\text { Sapaan ayah kepada anak dari kakak/adik perempuan ayah } \\
\text { kita }\end{array}$ \\
\hline
\end{tabular}

Faktor-Faktor Pergeseran Bahasa 
Pergeseran bahasa merupakan berpindahnya suatu pemakaian bahasa dari bahasa yang pertama yang diwariskan pendahulunya dengan bahasa yang baru dengan alasan apapun juga.

Pergeseran bahasa dapat terjadi karena perpindahan masyarakat yang menjadikan percampuran masyarakat di suatu daerah, dan akan menimbulkan keanekaragaman bahasa pada daerah tersebut. Dengan demikian hal itu dapat berdampak pada masyarakat itu sendiri untuk memilih bahasa mana yang dianggap paling sesuai digunakan tanpa menghiraukan kaedah yang berlaku pada budaya yang digunakan sebelum berpindah tempat.

Berdasarkan paparan pada konsep pergeseran bahasa sebelumnya dijelaskan bahwa Fasold (1984) menyatakan bahwa faktor-faktor pergeseran bahasa disebabkan oleh adanya bilingualisme, industrialisasi, bahasa asing yang lebih berprestice, urbanisasi atau migras dan faktor generasi, yang merupakan faktor-faktor yang dapat diidentifikasi sebagai penyebab pergeseran bahasa. Sejalan dengan pendapat Fasold, Chaer dan Agustina, (1995: 187) mengatakan pergeseran bahasa addalah menyangkut masalah penggunaan bahasa oleh sesorang penutur atau sekelompok penutur yang bisa terjadi sebagai akibat perpindahan dari satu masyarakat tutur ke masyarakat tutur lain. Kalau seorang atau sekelompok orang penutur pindah ke tempat lain yang menggunakan bahasa lain, dan bercampur dengan mereka akan terjadilah pergeseran bahasa. Pendatang atau kelompok pendatang ini untuk keperluan komunikasi mau tidak mau harus menyesuaikan diri dengan "menanggalkan" bahasanya sendiri, lalu menggunakan bahasa penduduk setempat.

\section{METODE PENELITIAN}

Penelitian ini dilakukan dengan menggunakan metode deskriptif kualitatif, untuk memberikan gambaran secara sistematis dan akurat terkait terjadinya pergeseran kata sapaan pada masyarakat Simalungun di Kecamatan Labuhan Deli.

\section{Data dan Sumber Data}

Data yang dikumpulkan peneliti adalah kumpulan kata sapaan yang digunakan penutur bahasa Simalungun dalam kehidupan sehari-hari di Kecamatan Labuhan Deli.

\section{Teknik Pengumpulan Data}

Teknik pengumpulan data dilakukan dengan menggunakan teknik simak yang dikembangkan lagi menjadi teknik simak bebas libat cakap dan teknik simak libat cakap.

\section{Teknik Analisis Data}

Adapun langkah-langkah analisis data dalam penelitian ini yaitu:

1. Reduksi data (data reduction) yaitu menyalin data dari hasil rekaman dalam bentuk percakapan ke data tulisan agar mempermudah untuk 
melakukan analisis, kemudian memilih data-data percakapan dan dikelompokkan berdasarkan tingkatan usia untuk dianalisis.

2. Penyajian data (data display) yaitu tahap untuk melakukan analisis:

a. Data dari percakapan dianalisis bagaimana pola pergeseran kata sapaan masyarakat Simalungun dalam ranah keluarga, ketetanggan, adat istiadat dan sosial berdasarkan tingkatan usia penutur.

b. Menganalisis karakteristik pergeseran kata sapaan masyarakat Simalungun berdasarkan ranah keluarga, ketetanggan, adat istiadat dan sosial berdasarkan tingkatan usia penutur.

c. Menganalisis faktor-faktor yang mempengaruhi pergeseran kata sapaan masyarakat Simalungun berdasarkan ranah keluarga, ketetanggan, adat istiadat dan sosial berdasarkan tingkatan usia penutur.

3. Conclusion drawing/verification yaitu menyimpulkan hasil analasis data dari percakapan masyarakat Simalungun berdasarkan ranah keluarga, ketetanggan, adat istiadat dan sosial berdasarkan tingkatan usia penutur.

\section{PENELITIAN DAN PEMBAHASAN}

\section{Bentuk Kata Sapaan Bahasa Simalungun yang Bergeser di Kecamatan Labuhan Deli}

\section{Ompung}

Ompung dikenal masyarakat Simalungun sebagai kata sapaan untuk memanggil orang tua dari ayah atau ibu baik orang tua laki-laki maupun perempuan. Namun dalam penelitian ini masyarakat Simalungun banyak yang tidak menggunakan kata sapaan tersebut dalam memanggil orang tua dari ayah. Mereka telah menggeser kata sapaan ompung menjadi oppung, inang dan tua. Pergeseran bentuk leksikal pada sapaan ompung menjadi oppung memang sangatlah sedikit. Ditinjau berdasarkan metode agih yang di dilanjutkan dengan teknik ganti pada konsonan [m] dalam kata sapaan ompung dan berganti menjadi konsonan [p] dalam kata sapaan oppung. Dengan demikian proses tersebut tergolong merupakan asimilasi atau menimbulkan bunyi baru.Hal ini tentunya telah mendapat perubahan bentuk secara leksikal, dengan demikian ompung yang merupakan sapaan terhadap orang tua dari ayah dan juga ibu telah bergeser menjadi oppung. Kemudian sebagian kalangan penutur bahasa Simalungun juga telah menggeser kata sapaan ompung menjadi inang.

Inang seharusnya adalah kata sapaan yang ditujukan kepada orang tua kita yang perempuan bukan sapaan untuk orang tua dari ayah atau ibu. Hal ini diyakini karena faktor generasi atau usia pengguna bahasa. Dari penelitian yang diperoleh sapaan inang yang digunakan untuk memanggil ompung biasanya digunakan oleh penutur pada usia anak-anak. Akan tetapi pada saat anak tersebut beranjak dewasa mereka akan kembali menggunakan kata sapaan yang lazimnya digunakan. 
Dengan demikian sapaan inang dalam bahasa Simalungun mendapat perluasan makna, yang awalnya inang hanya merupakan sapaan untuk orang tua perempuan kita, telah menjadi sapaan untuk orang tua dari orang tua kita itu sendiri. Kemudian kata sapaan ompung bergeser menjadi tua. Berdasarkan bentuk sapaan ini jelas telah berubah bentuk secara leksikal.

Pergeseran ini juga terjadi pada kalangan anak-anak sampai menginjak usia remaja. Hal ini disebabkan karena faktor bahasa Indonesia yang berada di tengah-tengah penutur bahasa Simalungun. Kata tua menurut kamus bahasa Indonesia adalah orang yang sudah lama hidup atau lanjut usia, sedangkan yang dipanggil dengan sapaan ompung sudah pasti lebih tua dari usia orang tuanya sendiri. Dengan demikian hal inilah yang dijadikan penutur bahasa Simalungun untuk menggeser kata sapaan ompung menjadi tua.

Beberapa kata sapaan di atas yang berubah atau bergeser secara leksikal yang berbentuk sinonim. Dalam Kridalaksana (2008: 222) pengertian sinonim adalah bentuk bahasa yang maknanya mirip atau sama dengan bentuk lain, kesamaan itu berlaku bagi kata atau kelompok kata atau kalimat, tetapi pada umumnya yang dianggap sinonim hanyalah kata-kata saja. Seperti pada kata sapaan ompung yang tergeser oleh leksikal oppung, inang dan tua apabila dilihat dari sudut linguistiknya perbedaan leksikal ompung dengan oppung, inang dan tua dapat dikategorikan menjadi bentuk sinonim sebab kata penggeser seperti oppung, inang dan tua memiliki arti yang sama yaitu kata sapaan untuk memanggil orang tua dari ayah atau ibu.

\section{Bapa/Amang}

Kata sapaan bapa/amang dikenal oleh masyarakat Simalungun dalam memanggil orang tua laki-laki. Namun dalam penelitian ini peneliti tidak pernah menjumpai seorang pun yang memanggil orang tuanya dengan kata sapaan amang, kebanyakan masyarakat Simalungun di Kecamatan Labuhan Deli telah menggeser kata sapaan tersebut menjadi bapak, papa dan ada juga masyarakat dalam rentang usia remaja yang menggeser dengan kata bos. Kata sapaan bapa/amang begeser menjadi bapak. Secara bentuk leksikal perubahan hanya terjadi pada penambahan atau penyisipan konsonan [k] pada leksikal bapak. Penambahan konsonan [k] tersebut jelas merubah bentuk leksikal bapa. Hal ini disebabkan karena penutur bahasa Simalungun yang berdiam di desa Pematang Johar menguasai dengan baik bahasa Indonesia. Bapak merupakan kata sapaan dalam bahasa Indonesia yang memang memiliki arti yang sama dengan bapalamangdalam bahasa Simalungun. Penguasaan bahasa Indonesia itu sendiri datang dari kebiasaan di sekolah yang secara rutin berkomunikasi dengan menggunakan bahasa Indonesia.

Kebiasaan berkomunikasi menggunakan bahasa Indonesia di kantor atau pabrik yang memang secara geografis letak antara desa Pematang Johar dengan 
Kawasan Industri Medan sangatlah dekat. Kemudian sapaan bapa/amang juga mengalami pergeseran menjadi papa. Dapat kita pahami perubahan bentuk leksikal yang terjadi pada kedua kata tersebut. Pada umumnya kata papa hanya digunakan oleh kalangan remaja dan anak-anak. Faktor penyebab terjadinya pergeseran tersebut adalah generasi atau usia pengguna bahasa. Usia muda juga menjadi pertanda dalam penyebutan kata sapaan untuk orang tua. Begitupun dalam penelitian ini juga ditemukan hal yang sama yaitu pergeseran kata sapaan pada usia muda, namun sapaan papa untuk memanggil orang tua laki-laki yang digunakan oleh penutur muda tersebut akan kembali menggunakan sapaan seperti lazimnya digunakan penutur dewasa lainnya.

Pergeseran sapaan bapa/amang menjadi bos juga terdapat di dalam penelitian ini. Hal ini sering terjadi bagi para penutur bahasa Simalungun yang berusia remaja. Bapa/amang telah berubah secara bentuk leksikal setelah mengalami pergeseran menjadi bos. Bos dalam kamus bahasa Indonesia merupakan orang yang berkuasa mengawasi dan memberikan perintah kepada para karyawan atau pemimpin di perusahaan. Dengan demikian sangat jelas yang menjadi faktor terjadinya pergeseran kata sapaan bapa/amang menjadi bos adalah faktor industrialisasi yang berada dekat dengan lingkungan desa Pematang Johar. Lingkungan industri sangat mempengaruhi terhadap pergeseran kata sapaan bapa/amang menjadi bos. Hal ini dikarenakan kebiasaan dalam lingkungan tersebut untuk memanggil seorang pimpinan dengan kata bos. Oleh karena itu kebiasaan tersebut berlanjut sampai ke lingkungan tempat tinggal. Berdasarkan uraian di atas dapat digolongkan sapaan bapak, papa dan bos yang memang secara bentuk leksikal berbeda dari kata sapaan bapa/amang dikategorikan dalam bentuk sinonim sebab leksikal bapak, papa dan bos memiliki arti yang sama yaitu kata sapaan untuk orang tua yang laki-laki.

\section{Inang}

Inang merupakan sapaan untuk orang tua kita yang perempuan, namun dari hasil penelitian ini penutur bahasa Simalungun telah menggeser sapaan tersebut dengan bentuk sapaan lain. Mamak, mama dan omak merupakan sapaan penggeser dari inang. Leksikal mamak sangatlah berbeda bentuk dengan leksikal inang. Hal ini terjadi karena pengaruh bahasa Indonesia yang sangat dominan di kalangan penutur bahasa Simalungun. Mamak merupakan berasal dari bahasa Indonesia. Berdasarkan kamus bahasa Indonesia mamak adalah sapaan untuk saudara laki-laki dari ibu. Namun dari berbagai hasil pengamatan ternyata bukan di penutur bahasa Simalungun saja kata sapaan mamak digunakan untuk memanggil ibu tapi dari berbagai suku tetangga yang ada di Labuhan Deli juga menggunakan mamak dalam memanggil ibu.

Kata sapaan inang juga bergeser menjadi mama. Sama halnya dengan penggeser sapaan di atas bahwa yang lebih dominan terjadinya pergeseran adalah 
pada kalangan usia anak-anak sampai remaja. Mama juga digunakan penutur bahasa Simalungun sebagai sebutan atau panggilan terhadap ibu. Hal ini terjadi karena faktor bahasa Indonesia yang sangat dominan bagi kalangan anak-anak dan remaja. Bahasa Indonesia tersebut mereka peroleh dari lingkungan sekolah, televisi dan bahkan ajaran dari orang tua sendiri. Orang tua sudah mengajarkan bahasa Indonesia di samping bahasa Simalungun bagi anak-anak mereka pada usia dini. Hal ini dilakukan karena orang tua takut bahwa anaknya tidak akan mengerti bahasa Indonesia ketika nanti masuk sekolah sehingga menghambat pemahaman tetang ilmu yang disampaikan oleh guru dengan menggunakan bahasa Indonesia.

Kata sapaan inang juga telah bergeser menjadi omak, berdasarkan bentuk leksikal sangat jelas perbedaan kedua kata tersebut, namun kata omak sangat mendekati dengan kata mamak yang juga merupakan salah satu penggeser dari sapaan inang. Berdasarkan uraian di atas dapat dilihat penggeser dari kata sapaan inang yaitu mamak, mama dan omak berubah secara leksikal dan dikategorikan leksikal mamak, mama dan omak merupakan sinonim dari inang karena ketiga kata penggeser tersebut memiliki arti yang sama dengan sapaan inang yaitu sapaan terhadap orang tua perempuan atau ibu.

\section{Abang}

Kata sapaan abang dalam bahasa Simalungun merupakan anak laki-laki yang usia kelahiranya lebih tua dari kita. Dalam penelitian ini tidak dijumpai penggeser dari kata sapaan tersebut. Kesamaan bentuk dan juga makna dengan bahasa Indonesia memungkinkan pemertahanan bahasa dalam sapaan itu.

\section{Botou}

Botou merupakan sapaan yang digunakan kepada saudara kita yang berbeda jenis kelamin. Berdasakan hasil penelitian tidak dijumpai penggeser dari kata sapaan ini. Namun ada beberapa kalangan usia yang memanggil nama langsung. Umumnya hal itu terjadi pada kalangan anak-anak.

Anggi

Anggi adalah salah satu sapaan yang digunakan masyarakat Simalungun untuk memanggil saudara laki-laki yang usia lebih muda darinya. Anggi juga telah mengalami pergeseran pada sebagian kalangan penutur bahasa Simalungun. Selain memanggil nama langsung penggesernya adalah adek dan ambia. Berdasarkan bentuk leksikal adek yang merupakan penggeser dari anggi memang berubah secara leksikal. Hal ini dikarenakan pengaruh bahasa Indoensia terhadap generasi muda Simalungun. Bilingualisme yang terdapat dalam diri penutur bahasa Simalungun ternyata sangat mempengaruhi terhadap pergeseran kata sapaan. Kemudian sapaan anggijuga bergeser menjadi ambia, ini biasanya terjadi pada kalangan orang dewasa. Faktor yang mempengaruhi terjadinya pergeseran tersebut karena transmigrasi penutur bahasa Simalungun. Simalungun terdiri dari 
beberapa dialek salah satunya adalah dialek Pematang Raya. Dengan bertransmigrasi ke daerah Labuhan Deli berdasarkan dialek yang dibawa dari asalnya membuat pergeseran kata sapaan terjadi di lingkungan barunya.

\section{Kaha}

Kaha merupakan salah satu kata sapaan yang digunakan oleh masyarakat penutur bahasa Simalungun. Berdasarkan data penelitian yang diperoleh bahwa kata sapaan kaha telah mulai terdapat pergeseran di dalam penggunaannya. Kata penggeser dari sapaan kaha yaitu kakak. Secara bentuk leksikal memang terdapat perubahan, dimana ada pergantian dan pelesapan konsonan di dalamnya. Konsonan [h] dalam kaha berubah menjadi konsonan [k] dalam kakak, kemudian juga disisipkan konsonan [k] di akhir kata sehingga membentuk leksikal kakak. Berdasarkan uraian di atas jelas membuat suatu perubahan dalam sapaan tersebut. Kakak berasal dari bahasa Indonesia, kata kakak itu sendiri merupakan suatu bentuk kata sapaan terhadap saudara yang lebih tua. Oleh penjelasan di atas dapat dikategorikan bahwa leksikal kakak merupakan sinonim dari kaha karena memiliki arti yang sama. Hal ini sangat memperkuat bahwa keberadaan bahasa Indonesia sangat menjamin terhadap terjadinya pergeseran bahasa. Kedwibahasaan salah satu faktor kuat yang mendukung proses terjadinya pergeseran kata sapaan dalam bahasa Simalungun.

\section{Amboru}

Amboru dikenal sebagai suatu bentuk kata sapaan dalam bahasa Simalungun. Amboru merupakan kata sapaan yang ditujukan kepada kakak ataupun adik perempuan dari ayah kita. Data yang ditemukan dalam penelitian ini didapati pergeseran dari kata sapaan amboru. Kata penggesernya adalah bou dan bibi. Pergeseran tersebut memang di dominasi oleh kalangan anak-anak dan remaja. Kata sapaan amboru bergeser menjadi bou menunjukan bahwa ada perubahan leksikal yang terdapat pada kedua sapaan ini.

Hal ini terjadi karena proses transmigrasi atau perpindahan penduduk yang awalnya merupakan bagian dari suku lain di luar Simalungun. Keinginan untuk menyesuaikan dengan lingkungan, namun karena keterbatasan penguasaan kata sapaan yang dia ketahui sehingga penutur menggunakan sapaan yang dia miliki atau yang dia ketahui untuk dipergunakan dalam memanggil seseorang yang dianggap sesuai dengan sapaan sebelum dia pindah ke lingkungan yang baru. Hal itu terbukti pada kata sapaan amboru di atas, dimana pergeseran yang mengakibatkan sapaan bou menggeser kata sapaan amboru. Bou diyakini penutur bahasa Simalungun di Labuhan Deli berasal dari bahasa Batak Toba.

Penutur bahasa Toba yang masuk ke lingkungan inilah yang membuat terjadinya pergeseran. Kemudian sama halnya dengan bibi yang merupakan salah satu sapaan penggeser dari kata sapaan amboru. Bibi merupakan suatu bentuk kata sapaan yang berasal dari Karo. Karena transimgrasi yang dilakukan oleh penutur 
bahasa Karo sehingga menimbulkan suatu bentuk kata sapaan yang baru muncul di tengah-tengah penutur bahasa Simalungun di Kecamatan Labuhan Deli. Dilihat berdasarkan makna kata bibi dalam bahasa Karo memiliki makna yang sama dengan amboru yaitu sama-sama sapaan terhadap saudara perempuan dari ayah. Dengan demikian leksikal bou dan bibi merupakan sinonim dari amboru dalam bahasa Simalungun. Berdasarkan penjelasan di atas dapat ditarik kesimpulan bahwa karena perpindahan penduduk ke lingkungan yang baru ternyata dapat menggeser suatu bentuk kata sapaan yang sebelumnya digunakan oleh penutur pada lingkungan tersebut.

\section{Makkela}

Kela merupakan salah satu kata sapaan yang digunakan oleh penutur bahasa Simalungun dalam memanggil suami dari amboru atau suami dari saudara perempuan ayah kita.Kela merupakan hasil proses pergeseran dari kata sapaan makkela. Berdasarkan bentuk leksikal kela mengalami perubahan setelah terjadinya pelesapanpada satuan lingual dalam kata makkela yaitu 'mak'. Lesapnya mak dalam kata makkela sehingga membentuk sapaan baru yaitu kela. Hal ini terjadi pada kalangan usia anak-anak sampai remaja, dan ini merupakan karena faktor generasi atau usia pengguna bahasa. Diyakini pada usia tertentu atau setelah dianggap dewasa maka sapaan yang lazimnya digunakan oleh penutur bahasa Simalungun akan kembali mereka gunakan, karena mereka menganggap bahwa sapaan kela hanyalah sapaan yang digunakan oleh anak-anak. Dalam penelitian ini tidak dijumpai ada sinonim lain daripada makkela selain kela, artinya hanya leksikal kela sajalah satu-satunya yang menjadi penggeser dari sapaan makkela.

\section{Tulang}

Tulang merupakan salah satu sapaan yang digunakan masayarakat Simalungun dalam memanggil atau menyebut seseorang adik laki-laki dari ibu kita. Berdasarkan penelitian ini tidak dijumpai adanya pergeseran dalam sapaan ini. Hal ini diyakini karena penutur bahasa Simalungun sangat menghormati seseorang yang dipanggil dengan sapaan tulang. Olehkarena itu penutur bahasa Simalungun sangat berhati-hati agar bagaimana supaya tulang tersebut tidak merasa kecewa dengan kita. Salah satu cara yang dilakukan adalah memanggil atau menyebut sapaan tersebut dengan sangat jelas tanpa ada perubahan bentuk leksikal sedikitpun.

\section{Atturang}

Demikian halnya dengan sapaan atturang yang merupakan isteri dari tulang. Dikatakan tulang ataupun atturang menurut adat Simalungun adalah bagian daripada tondong atau salah satu bentuk sistem kekerabatan yang terdapat dalam 'tolu sahundulan'. Tondong berperan sebagai pemberi nasihat atau sumber berkat. Berdasarkan pandangan seperti inilah yang membuat masyarakat 
Simalungun sangat menghargai dan menghormati tondong yang di dalamnya pasti ada tulang dan atturang. Dengan demikian salah satu bentuk cara penghormatan dan sikap menghargainya adalah dengan tidak merubah suatu bentuk panggilan atau sapaan kepada tulang dan atturang itu sendiri. Berdasarkan hal tersebut maka di dalam penelitian ini tidak dijumpai pergeseran bentuk kata sapaan yang terjadi pada sapaan tulang dan atturang.

\section{Parumaen}

Parumaen adalah salah satu bentuk sapaan yang lazimnya digunakan penutur bahasa Simalungun dalam memanggil atau menyapa isteri dari anak atau dalam bahasa Indonesia disebut menantu. Dalam penelitian ini tidak dijumpai adanya bentuk sapaan penggeser dalam memanggil parumaen. Namun ada suatu perbedaan yang memang terjadi di kalangan penutur bahasa Simalungun dalam pemanggilan parumaen ini. Ibu mertua daripada parumaen ini jarang sekali menyapa parumaennya dengan sapaan parumaen, tetapi langsung menyebut nama. Lain halnya dengan ayah mertua yang memang dalam penelitian ini selalu memanggil atau menyebut isteri dari anakanya dengan sapaan parumaen. Berdasarkan informasi yang diperoleh tidak diperkenankan menurut adat parumaen dan ayah mertuanya berbicara langsung tanpa ada perantara yang menjembatani pembicaraan mereka. Dengan terbatasnya berkomunikasi antara ayah mertua dan parumaententu sangat menjaga terjadinya pergeseran kata sapaan parumaen ini sendiri.

\section{Nasibesan}

Nasibesan adalah salah satu bentuk sapaan yang memang digunakan penutur bahasa Simalungun dalam berkomunikasi. Nasibesan adalah sapaan yang digunakan untuk memanggil isterinya adik/abang dari isteri kita. Berdasarkan penelitian ini tidak dijumpai adanya pergeseran yang terjadi dalam sapaan ini. Hal ini diyakini karena di dalam adat Simalungun antara nasibesan tidak boleh sembarangan berkomunikasi, artinya ada suatu penjagaan jarak berkomunikasi antarsesama yang ber-nasibesan. Dengan adanya jarak tersebut tentu mempertahankan suatu bentuk sapaan yang memang jarang antar penutur tersebut berkomunikasi.

\section{Hela}

Hela merupakan suatu bentuk sapaan yang digunakan masyarakat penutur bahasa Simalungun dalam memanggil atau menyebut seorang suami dari putrinya. Berdasarkan hasil dari penelitian ini pergeseran yang ditemukan terhadap kata sapaan ini adalah dengan memanggil nama langsung. Hal ini terjadi karena mertua menganggap bahwa hela tersebut sudah dianggap menjadi anak yang memang biasa dipanggil nama oleh orang tuanya.

\section{Gawei/Eda}


Gawei atau eda merupakan bentuk sapaan timbal balik bagi perempuan yang digunakan untuk memanggil isteri dari abang atau adik kita. Berdasarkan hasil penelitian yang dilakukan bahwa kedua bentuk kata sapaan yang memiliki sinonim sama itu terdapat suatu perbandingan jarak yang sangat jauh di dalam penyebutan sapaan tersebut, bahwa kata sapaan gawei sangat jarang digunakan oleh penutur bahasa Simalungun sedangkan eda sangat dominan digunakan.

\section{Lawei/Lae}

Lawei atau lae adalah bentuk kata sapaan timbal balik bagi laki-laki yang digunakan untuk memanggil suami dari kakak atau adik kita. Berdasarkan penelitian ini ada suatu bentuk persamaan dari kata sapaan sebelumnya yaitu gawei dan eda, dimana terdapat dua kata sapaan yang lazim digunakan tetapi kenyataanya ada perbedaan jarak yang sangat jauh atau dominisasi dari satu kata sapaan yang digunakan oleh penutur bahasa Simalungun itu sendiri.

Kata sapaan yang lebih dominan digunakan oleh masyarakat penutur bahasa Simalungun adalah kata sapaan lae. Lae kerap digunakan penutur bahasa Simalungun karena ada persamaan kata sapaan dengan penutur bahasa batak lainnya. Dalam kenyataan di lapangan lae sangat sering digunakan oleh para penutur bahasa Simalungun untuk menyapa seseorang walaupun sebelumnya tidak saling mengenal karena lae sudah menjadi suatu bentuk sapaan dalam pergaulan. Berdasarkan hasil penelitian ada suatu bentuk pergeseran yang terjadi pada kata sapaan lae dan pergeseran tersebut terjadi dalam ranah sosial khusunya di warung kopi bagi para penutur usia dewasa.

Bentuk sapaan penggesernya adalah lek. Berdasarkan bentuk leksikal lae dan lek terdapat perubahan bentuk, dimana ada suatu pergantian satuan lingual di dalam sapaan tersebut. Vokal [a] dalam lae berubah menjadi [e] dan vokal [e] pada leksikal lae juga mendapat perubahan menjadi bentuk konsonan [k] sehingga membentuk lek. Hal ini terjadi karena faktor generasi atau usia pengguna bahasa, biasanya yang sering menyebut lekterjadi pada ranah usia remaja. Namun pada saat menginjak dewasa nanti atau setelah berkeluarga kebiasaan tersebut akan berangsur-angsur kembali seperti semula. Hal ini menunjukan suatu bentuk kesopaan dalam berbicara bagi para penutur bahasa Simalungun.

\section{Pahompu}

Pahompu adalah salah satu bentuk kata sapaan yang digunakan masyarakat Simalungun untuk memanggil anak dari anak kita atau dalam bahasa Indonesia cucu. Dalam penelitian ini tidak ada suatu bentu kata sapaan penggeser dari kata sapaan pahoppu. Hal ini disebabkan karena setiap penutur bahasa Simalungun pada lingkungan penelitian ini tidak memanggil pahoppuuntuk memanggil cucunya, melainkan nama langsung yang digunakan oleh penutur dalam berkomunikasi.

\section{Nono}


Nono merupakan bentuk kata sapaan yang dipergunakan masyarakat Simalungun untuk memanggil cucu dari anaknya. Pergeseran yang terjadi pada kata sapaan ini tidak ada ditemukan pada penelitian ini karena sangat jarang ada penutur bahasa Simalungun yang memang memiliki usia dimana dia memiliki seorang nono. Sama halnya dengan sapaan pahoppu, nono juga hanya sebagai kata perwakilan dari semua nono-nono yang lain. Maksudnya adalah kata sapaan nonotidak dipergunakan penutur dalam penelitian ini sebagai suatu bentuk sapaan langsung terhadap objek atau seseorang yang dipanggil dengan kata sapaan nono.

\section{Bapa Tua dan Inang Tua}

Bapa tua dan inang tua merupakan kata sapaan terhadap sepasang suami isteri dalam bahasa Simalungun. Bapa tua digunakan untuk abang yang paling sulung atau tua dari ayah kita. Sedangkan inang tua adalah sapaan untuk isteri dari bapa tua itu sendiri. Berdasarkan hasil dari penelitian yang dilakukan ada beberapa penutur yang telah menggeser kata sapaan bapa tua dengan sapaan lain. Bentuk lain yang digunakan penutur dalam memanggil bapa tua adalah tua danpak tua. Berdasarkan bentuk leksikal terjadi perubahan dimana ada pelesapan kata bapa sehingga meninggalkan tua. Dari hasil pelesapan inilah yang digunakan penutur untuk menjadikan sapaan dalam menggeser sapaan bapa tua tersebut.

Pergeseran bapa tua menjadi pak tua. Berdasarakan bentuk leksikal ada suatu perubahan yang terjadi pada leksikal tersebut, yaitu leksikal bapa telah berubah menjadi pak dan tua tetap pada posisinya. Oleh karena perubahan tersebut sehingga menimbulkan bentuk sapaan baru yang digunakan oleh sebagian penutur bahasa Simalungun di lingkungan desa Pematang Johar. Sejalan dengan hal itu pergeseran yang sama juga terjadi pada kata sapaan inang tua, yang merupakan isteri dari bapa tua. Hal ini sangat sulit untuk dipisahkan karena kedekatan bentuk kekeluargaan yang menjadi faktor, bahwasanya hapir pada saat bersamaan kata sapaan ini selalu digunakan bersama. Kata sapaan penggeser dari kata sapaan inang tua adalah tua dan mak tua.Faktor yang mempengaruhi dalam terjadinya pergeseran tersebut ialah karena penguasaan bahasa Indonesia dalam diri penutur bahasa Simalungun.

\section{Bapa Tongah dan Inang Tongah}

Bapa tongah dan inang tongah adalah salah satu kata sapaan yang digunakan oleh masyarakat Simalungun. Bapa tongah digunakan masyarakat Simalungununtuk memanggil saudara lak-laki ayah yang usianya berada di tengah-tengah atau tidak yang paling tua dan tidak pula yang paling muda. Begitu pula dengan inang tongah merupakan sapaan yang ditujukan kepada isteri dari bapa tongah itu sendiri. Berdasarkan penelitian ini tidak dijumpai terjadinya pergeseran dalam kata sapaan tersebut. Hal yang meperkuat dalam pemertahanan kata sapaan ini adalah karena jarang sekali sapaan ini digunakan. Sapaan bapa tongah dan inang tongah hanya dapat didengar pada keluarga yang memiliki 
banyak saudara laki-laki, atau minimal terdapat tiga orang saudara laki-laki dari ayah. Maka saudara yang usianya berada di tengah-tengah atau tidak paling tua dan tidak yang paling muda itulah sapaan bapa tongah disematkan.

\section{Bapagian dan Inanggian}

Bapagian merupakan kata sapaan yang lazimnya digunakan masyarakat Simalungun dalam memanggil saudara laki-laki dari ayah yang usianya paling muda atau bungsu. Kemudian inang gian merupakan kata sapaan yang ditujukan kepada isteri daripada bapagian itu sendiri. Namun pada saat sekarang ini penutur bahasa Simalungun di Kecamatan Labuhan Deli kerap menggeser kata sapaan tersebut menjadi bentuk kata sapaan yang lain.

Salah satu sapaan penggeser dari bapagian adalah kian. Berdasarkan bentuk leksikal bapagian telah mengalami perubahan menjadi kian, perubahan tersebut terlihat jelas dan dapat dipahami menjadi sebuah perubahan dalam bentuk secara leksikal, hal itu dapat dibuktikan dengan menggunakan metode agih dilanjutkan dengan teknik lesap dan ganti. Sebagian dari satuan lingual dalam leksikal bapagian yaitu 'bapa' terjadi pelesapan, oleh karena itu dihasilkan leksikal gian, kemudian konsonan [g] pada gian mengalami pergantian menjadi konsonan [k] sehingga membentuk kian yang digunakan penutur bahasa Simalungun menjadi sebuah kata sapaan untuk menyapa saudara laki-laki dari ayah yang usianya paling muda atau bungsu. Sama halnya dengan bapagian sapaan inang gian juga mengalami pergeseran yang sama yaitu menjadi kian. Hal ini terjadi karena faktor generasi atau usia pengguna bahasa yang lebih dominan digunakan oleh anak-anak sampai remaja untuk menggunakan sapaan tersebut untuk memanggil bapagian dan inanggian.

Kemudian terdapat dibeberapa kalangan yang menggeser kata sapaan bapagian menjadipanggidan inanggian menjadi nanggi.Dilihat dari bentuk leksikal memang terdapat pelesapan sebagian dari satuan lingual leksikal bapagian dan inanggian. Satuan lingual yang dilesapkan adalah ' $b a$ ' pada bapagian sehingga menghasilkan 'panggian'dan ' $i$ ' pada inanggian sehingga membentuk leksikal 'nanggian'.Hal yang mendasari terjadinya pergseran tersebut adalah karena faktor transmigrasi penutur bahasa Simalungun dari daerah Kecamatan Negeri Dolok Kabupaten Simalungun yang memang menganggap panggian dan nanggian adalah kata sapaan yang lazim digunakan di daerah mereka tersebut. Berdasarkan uraian di atas kata sapaan penggeser seperti kian, panggian, dan panggi dapat dikategorikan sebagai sinonim dari kata sapaan bapagian. Kemudian sapaan penggeser seperti kian, nanggian dan nanggijuga merupakan suatu bentuk sinonim dari kata sapaan inanggian.

\section{Sanina}

Sanina adalah sebuah bentuk sapaan dalam bahasa Simalungun yang digunakan untuk memanggil saudara ataupun yang semarga dengan diri kita 
sendiri. Namun sebagian kalangan penutur bahasa Simalungun telah menggeser kata sapaan tersebut menjadi sapaan yang lain atau baru. Berdasarkan hasil penelitian pada ranah sosial penutur bahasa Simalungun pada tataran usia remaja sampai menginjak dewasa menggeser sapaan sanina menjadi appara. Jelas secara bentuk leksikal memang sapaan tersebut telah berubah secara leksikal. Hal yang mendasari terjadinya pergeseran tersebut adalah karena kedwibahasaan para penutur bahasa Simalungun yang mendiami lingkungan tempat tinggalnya, oleh karena keberadaannya tersebutlah maka muncul suatu bentuk sapaan penggeser dari sapaan yang lazimnya digunakan oleh penutur bahasa Simalungun itu sendiri. Hal itu terbukti pada bentuk kata sapaan penggeser dari kata sapaan sanina yaitu appara. Appara merupakan kata sapaan yang biasa digunakan oleh penutur bahasa batak Toba. Namun karena penguasaan bahasa batak Tobayang dimiliki oleh penutur bahasa Simalungun itulah memicu munculnya sapaan lain yang menggeser kata sapaan yang secara turun temurun digunakan oleh masyarakat Simalungun.

\section{Panogolan}

Panogolan adalah suatu bentuk kata sapaan yang digunakan oleh masyarakat Simalungun untuk memanggil anak dari kakak atau adik perempuan kita. Kata sapaan ini sangat jarang digunakan oleh penutur bahasa Simalungun karena biasanya penutur memanggil seseorang yang menjadi sasaran untuk kata sapaan panogolan ini dengan memanggil nama langsung si anak. Biasanya kata sapaan panogolan digunakan pada acara-acara yang bersentuhan dengan adatistiadat. Namun pada kehidupan sehari-hari kata panogolan selalu diganti oleh nama langsung anak tersebut.

\section{Faktor-Faktor Penyebab Pergeseran Kata Sapaan Pada Masyarakat Simalungun di Kecamatan Labuhan Deli Bilingualisme Masyarakat}

Kebiasaan menggunakan dua bahasa atau lebih merupakan suatu hal yang sangat biasa bagi masyarakat Simalungun yang berdomisili di Kecamatan Labuhan Deli khusunya di Desa PematangJohar. Hal ini terjadi karena penutur bahasa Simalungun tidak menutup kemungkinan melakukan kontak bahasa dengan penutur bahasa lain yang berada di sekitar lingkunganya. Bahasa lain selain bahasa Simalungun yang dikuasai oleh sebagian penutur bahasa Simalungun yang berada di tataran usia dewasa adalah antara lain bahasa Karo, Toba, Indonesia dan Jawa. Dengan kemampuan tersebut ternyata terjadi suatu dampak yang sangat merugikan para penutur bahasa Simalungun itu sendiri.

Suatu bentuk kerugian tersebut adalah terjadinya pergeseran kata sapaan dalam bahasa Simalungun dan pergeseran tersebutlah yang akan memicu terjandinya kepunahan bahasa. Dari beberapa data sebelumnya ada ditemukan pergeseran kata sapaan yang disebabkan karena kemampuan bilingualisme atau 
kedwibahasaan masyarakat Simalungun di Kecamatan Labuhan Deli yaitu sapaan amboru yang telah bergeser menjadi bou. Boumerupakan suatu bentuk sapaan yang berasal dari batak Toba. Namun, dengan kemampuan bilingualisme masyarakat Simalungun serta seringnya terjadi kontak sosial antara penutur bahasa Simalungun dengan penutur bahasa Toba membuat sapaan amboru mengalami pergeseran.

Ranah ketetanggaan terdapat pula penutur bahasa Simalungun yang sudah menggeser kata sapaan amboru menjadi bibi. Bibi merupakan suatu bentuk sapaan yang berasal dari bahasa Karo. Hal ini tentunya telah biasa dilakukan oleh penutur bahasa Simalungun karena lingkungan yang memang sangat memungkinkan untuk mengalami fenomena tersebut.

\section{Migrasi dan Urbanisasi}

Masyarakat Simalungun yang berada di desa Pematang Johar merupakan perantau yang datang dari berbagai daerah untuk mengadu nasib di Kecamatan Labuhan Deli khususnya desa Pematang Johar. Hampir semua masyarakat Simalungun di tempat ini bukan putra daerah asli yang memang lahir di Pematang Johar, melainkan datang dari asal yang berbeda-beda dan menempati wilayah itu dan berkumpul menjadi satu kesatuan yang sangat harmonis.

Secara bahasa memang tidak ada pengaruh yang sangat sulit untuk berkomunikasi, namun dalam penyapaan seseorang tentu ada perbedaan yang membuat masyarakat Simalungun sekarang tetap menggunakan kata sapaan tersebut. Misalnya dalam kata sapaan inang, pada dasarnya inang merupakan kata sapaan untuk memanggil orang tua perempuan kita, tetapi dalam penelitian ini peneliti menjumpai kata sapaan inang digunakan untuk memanggil orang tua atau ibu dari ayah kita.

Ternyata berdasarkan pengamatan yang dilakukan pemakai kata sapaan inang untuk memanggil orang tua atau ibu dari ayah kita adalah masyarakat Simalungun yang berasal dari Seribu Dolok salah satu Kecamatan yang berada di Kabupaten Simalungun. Kemudian terdapat juga bentuk sapaan yang telah mengalami pergeseran yaitu ompungmenjadi tua. Hal ini terjadi karena penutur yang menggunakan sapaan itu bermigrasi dari daerah asalnya yang berada di Kecamatan Raya Kabupaten Simalungun.

\section{Faktor Alih Generasi}

Masyarakat tutur merupakan gabungan dari sekelompok manusia yang setidak-tidak sudah mengenal satu variasi bahasa di dalam lingkungannya. Gabungan tersebut terdiri dari manusia tua dan muda atau dari semua tataran usia seorang manusia normal. Di dalam berinteraksi selalu muncul perbedaan variasi bahasa pada setiap rentang usia pengguna bahasa tersebut. Usia muda ternyata lebih dominan dalam perubahan itu. Sama halnya ketika menggunakan kata 
sapaan dalam menegur atau memanggil seseorang, tentunya ada kata sapaan yang lazim digunakan oleh penutur bahasa Simalungun.

Berdasarkan data yang diperoleh terdapat sapaan yang telah bergeser karena faktor genarasi atau pada usia pengguna bahasa, yang dominan pada kalangan anak muda. Di usia tertentu sekelompok anak muda menggunakan bahasayang berbeda dengan orang-orang yang usianya di atas mereka. Pergeseran yang mereka timbulkan akan membuat sekelompok penutur yang seusia mereka paham dengan hal tersebut. Pergeseran yang terjadi dapat ditimbulkan karena adanya penambahan, pengurangan, ataupun pergantian satuan lingual dalam suatu bentuk sapaan yang mereka gunakan. Namun dalam hal pergeseran yang disebabkan karena faktor generasi ini jarang sekali mereka pertahankan pergeseran tersebut, artinya ketika beranjak dewasa mereka akan kembali pada hakikatnya atau menggunakan kembali kata sapaan yang lazimnya digunakan oleh orang-orang dewasa.

\section{Faktor Industrialisasi}

Kawasan industri yang terdapat di sekitar wilayah Kecamatan Labuhan Deli khususnya di desa Pematang Johar juga memberikan dampak yang sangat jelas dalam terjadinya pergeseran bahasa Simalungun. Amang yang masyarakat Simalungun kenal merupakan panggilan terhadap ayah kandung kita sudah tergeser oleh kata sapaan baru yaitu papa, bapak dan ada juga yang memanggil dengan kata bos. Khusus kata sapaan bos, yang artinya merupakan suatu panggilan terhadap atasan atau pimpinan dalam sebuah perusahaan atau lembaga indsutri lainnya, ternyata juga merambat ke berbagai ranah penggunaan bahasa Simalungun di Kecamatan Labuhan Deli.

Masyarakat usia dewasa lebih dominan menggunakan kata sapaan bos ini untuk menyebut ayah kandungnya ketika berkomunikasi dengan teman-teman sebaya.Padahal seharusnya dipanggil dengan kata sapaan amangatau bapa. Kebiasaan yang dilakukan di lingkungan pekerjaan ternyata tidak tinggal di lingkungan pekerjaan melainkan terbawa-bawa sampai ke lingkungan tempat tinggal. Dengan demikian ternyata keberadaan industrialisasi yang memang sangat dekat dengan wilayah pemukiman desa Pematang Johar berpengaruh dalam terjadinya pergeseran bahasa Simalungun di Kecamatan Labuhan Deli.

\section{Bahasa Asing Lebih Berprestise}

Masyarakat Simalungun yang hidup di lingkungan Desa Pematang Johar Kecamatan Labuhan Deli memang terbilang cukup sangat kaya akan budaya, karena bukan hanya suku Simalungun saja yang bertempat disitu namun sukusuku lain yang masuk dalam kategori batak juga banyak mendiami desa itu. Namun, secara kebiasaan yang sudah terjadi sejak lama masyarakat di luar suku Simalungun yang berada di desa itu rata-rata menggunakan bahasa Simalungun walaupan pada dasarnya dia bukan suku Simalungun. 
Mereka yang bukan Simalungun mencoba menyesuaikan diri dengan lingkungan yang memang mayoritas Simalungun. Berdasarkan penjelasan di atas bahwasanya bahasa dari suku-suku di luar Simalungunlah yang disebut bahasa asing. Walaupun asing namun keberadaannya mampu menggeser kata sapaan dari bahasa Simalungun yang sudah lama digunakan oleh para penutur bahasa Simalungun di desa Pematang Johar. Salah satu contohnya adalah bibi. Bibi bukanlah kata sapaan asli Simalungun melainkan berasal dari bahasa Karo. Hal ini meyakinkan kita bahwa peran dari bahasa asing yang berada di lingkungan desa Pematang Johar yang memang mayoritas setiap hari masyarakat disana menggunakan bahasa Simalungun dalam berkomunikasi lebih berprestise dari pada bahasa Simalungun itu sendiri.

Kata sapaan bou juga sebelumnya tidak dikenal oleh masyarakat Simalungun, karena bou merupakan kata sapaan yang berasal dari bahasa batak Toba. Dengan kedua kata sapaan ini menyakinkan peneliti bahwa bahasa asing lebih berprestise dari pada bahasa Simalungun itu sendiri. Pada masa sekarang tentunya orang tua juga mengajarkan bagi anak mereka yang memang masih berada pada tahap pemerolehan bahasa untuk mengetahui bahasa Indonesia yang memudahkan mereka nanti dalam penyesuaian di lingkungan sekolah. Ternyata hal ini juga mempengaruhi terjadinya pergeseran kata sapaan karena mereka sudah terbiasa dengan bahasa Indonesia. Salah satu contohnya adalah kata sapaan bapak dan mamak merupakan kata sapaan yang berasal dari bahasa Indonesia, dan ada beberapa anak di dalam penggunaan kata sapaannya yang berasal dari bahasa Indonesia yaitu kata sapaan papadan mama. Hal itu terjadi karena adanya peran orang tua yang mendukung anaknya melakukan atau menggunakan sapaan yang tidak sesuai dengan khaidah bahasa Simalungun. Oleh karena itu dituntut juga peran orang tua dalam hal melestarikan keutuhan dari bahasa Simalungun.

\section{KESIMPULAN}

Berdasarkan atas paparan pada bab satu sampai bab lima dapat disimpulkan sebagai berikut.

Masyarakat Simalungun di desa Pematang Johar Kecamatan Labuhan Deli menggunakan kata sapaan untuk mengatur hubungan kekerabatan agar memperoleh keharmonisan dan keserasian dalam kehidupan bermasyarakat dan berkeluarga. Adapun kata sapaan yang seharusnya digunakan masyarakat Simalungun di desa Pematang Johar yaitu ompung, bapa/amang, inang, amboru, makkela, bapagian/bapa anggi, inanggian/inang anggi, bapa tongah, bapa tua, lae, parumaen, panogolan, kaha, anggi, sanina.

Kata sapaan yang seharusnya digunakan dalam kehidupan sehari-hari pada masyarakat Simalungun sudah mengalami pergeseran pada setiap jenjang usia penuturnya dan di setiap ranah penggunaan bahasanya. Namun semua itu telah mengalami pergeseran menjadi seperti bentuk sapaan berikut: tua, inang, bapak, 
papa, mamak, mama, bou, bibi, kela, kian, tongah, tua, lek, appara. Kata sapaan yang mengalami pergeseran tersebut lebih banyak dilakukan oleh remaja usia 12 sampai 25 tahun. Sedangkan pada usia dewasa umur 26 sampai 50 tahun tingkat terjadinya pergeseran kata sapaan tidak terlalu banyak dari usia 12 sampai 25 tahun.

Faktor-faktor yang menyebabkan terjadinya pergeseran kata sapaan adalah karena bilingualisme masyarakat, migrasi dan urbanisasi, peralihan antar generasi, letak pemukiman penduduk berdekatan dengan daerah industrialisasi dan tingginya prestise bahasa asing pada penutur bahasa Simalungun itu sendiri.

\section{DAFTAR PUSTAKA}

Agustono, dkk. 2012. Sejarah Etnis Simalungun. Medan

Brown, R.W., dan A.Gillman, 1968. "The Pronouns of Power and Solidarity" dalam Fishman, J.A. Reading in the Sociology of Language.The Hague: Moulon.

Chaer, Abdul dan Leonie Agustina. 1995. Sosiolinguistik: Suatu Pengantar. Jakarta: Rieneka Cipta.

Faslod, Ralph. 1984. The Sociolinguistics of Society. New York: Blackwell.

Fishman, J.A. 1968. Reading in the Sociology of Language. Den Haag-Paris: Mouton.

Hymes, Dell. 1974. Foundation of Sociolinguistics. Philadelphia: University of Pensylvania Press.

Kridalaksana, Harimurti. 2008. Kamus Linguistik. Jakarta: Gramedia Pustaka Utama.

Meilala, Lusianna. 2002. "Kata Sapaan Dalam Bahasa Karo”. (Tesis). USU.

Miles, Matthew B dan A. Michael Huberman. 1988. Qualitative Data Analysis. Terjemahan Tjetjep Rohendi. 1992. Analisis Data Kualitatif. Universitas Indonesia.

Rahardi, Kunjana. 2006. Dimensi-dimensi Kebahasaan. Yogyakarta: Gelora Aksara Pratama.

Romaine, S. 1995. Language In Society. Oxford University Press.

Sinaga, Salmon. 2002. Adat ni Simalungun. Pematang Siantar.

Sitanggang, dkk. 2004. Kamus Pelajar. Jakarta: Universitas Indonesia.

Sudaryanto.1993.Metode dan Aneka Teknik Analisis Bahasa Pengantar Penelitian

Wahana Kebudayaansecara Linguistik. Yogyakarta: Duta Wacana University Press.

Suparlan, Parsudi. 1994. Metode Penelitian Kualitatif. Jakarta: Universitas Indonesia. 